\title{
A New Malachite Damselfly (Synlestidae: Odonata) from the Eocene of Patagonia, Argentina ${ }^{1}$
}

\author{
Julián F. Petrulevičius ${ }^{2}$
}

\begin{abstract}
A new synlestid zygopteran, Madres delpueblo n. gen. n. sp., is described from the middle Eocene of Río Pichileufú, Patagonia, Argentina. The new genus is characterised by wing characters such as the discoidal cell narrow and long; Ax2 aligned with the arculus; MP distinctly curved after its origin; $\mathrm{CuP}+\mathrm{AA}$ fused to the hind margin half of the length of the discoidal cell; $\mathrm{CuP}$ closer to Ax2 than to Ax1. Needle damselflies or Malachites are represented in other two Patagonian Eocene localities, by nymphs and adults. The new genus enlarges the fossil record of Lestomorpha in Argentina to four extinct genera: Promegalestes, Austroperilestes, Inacayalestes and Madres $\mathrm{n}$. gen. versus two Recent ones: Lestes and Archilestes.
\end{abstract}

Key Words. Synlestidae, Madres del pueblo n. gen. n. sp., Eocene, Patagonia, Argentina.

\section{Introduction}

The family Synlestidae has Recent species in South Eastern Asia, Eastern Australia, Africa and Central America (Tsuda 2000). Fossil Synlestidae are recorded from three neighbour Patagonian Eocene localities, i.e., Nahuel Huapi Este (ca. $54 \mathrm{Ma}$ ) (Petrulevičius 2015), Río Pichileufú (this work), Confluencia (Ypresian?) (Petrulevičius 2013) (synlestid? nymph). A fourth record from the Northern Hemisphere consists of a nymph and several adults from the Eocene Baltic amber (Bechly and Wichard 2008). Other less certain records of malachites come from the Tertiary of USA and the Paleocene of Canada (Greenwalt and Bechly 2014).

The single specimen comes from the Patagonian Lutetian locality of Río Pichileufú (47 Ma), Río Negro, Argentina (Petrulevičius 2013). The locality is renowned for its very high plant diversity (Wilf et al. 2005; Wilf 2012). Previously reported insects from the same site are the myrmecine ant Archimyrmex piatnitzkyi (Viana and Haedo Rossi, 1957) (Dlussky and Perfilieva 2003), and the pentatomoid bug Acanthocephalonotum martinsnetoi Petrulevičius and Popov, 2014. Patagonian Eocene localities are exponentially increasing their known plant and insect diversity in recent years through sustained efforts to collect and describe their fossils (Petrulevičius 2001, 2009, 2013, 2015, 2016, 2017a, b; Wilf et al. 2003, 2005; Petrulevičius and Nel 2005; Petrulevičius et al. 2010; Wilf 2012; Petrulevičius and Popov 2014).

\footnotetext{
${ }^{1}$ Submitted on December 18, 2018. Accepted on December 23, 2018. Last revisions received on December 25, 2018.

${ }^{2}$ CONICET - División Paleozoología Invertebrados, Facultad de Ciencias Naturales y Museo, Universidad Nacional de La Plata, Paseo del Bosque s/n, La Plata (1900), Argentina. Email: levicius@fcnym.unlp.edu.ar
}

DOI: 10.9784/LEB6(2)Petrulevicius.01

Electronically available on December 25, 2018. 
The specimen studied here represents the second odonatan from Río Pichileufú and the first one belonging to Lestomorpha Bechly, 1996. The first is the dragonfly Treintamilun vuelvenlucha Petrulevičius, 2017 (Frenguelliidae) (Petrulevičius 2017). The Frenguelliidae are endemic from the Eocene of Patagonia and controversially considered either basal Euepiproctophora by Bechly and Poinar (2013), Petrulevičius and Nel (2003, 2007, 2013) and Petrulevičius et al. (2011), or Zygoptera by Nel and Arillo (2006), Nel et al. (2008), Lak et al. (2009), and Greenwalt and Bechly (2014).

\section{Methods}

The material was collected from the Volcanic caldera-lake beds, Río Pichileufú, quarry RP4 (field descriptor "PichiPrem"), new locality discovered by Ariana "Premgi" Paulina Carabajal in 2016 and lateral equivalent (200 hundred meters) to quarry RP3 from Wilf et al. (2005), Pilcaniyeu, Province of Río Negro, Patagonia, Argentina. The locality is placed at the palaeolatitude $\sim 46^{\circ} \mathrm{S}$ and was dated using $40 \mathrm{Ar} / 39 \mathrm{Ar}$ analyses in Wilf et al. (2005) and recalculated in Wilf (2012), giving an age of $47.74 \pm 0.05 \mathrm{Ma}$.

In this work, I follow the wing venation nomenclature of Kukalová-Peck (1983), amended by Kukalová-Peck $(1991,2009)$, also contributions by Riek and Kukalová-Peck (1984), Nel et al. (1993), Bechly (1996), and Petrulevičius and Gutiérrez (2016). The higher classification of fossil and extant Odonata is based on the phylogenetic system of Bechly $(1996,2007)$.

The new species was drawn and photographed in detail using a camera lucida and a Leica digital camera (DMC2900), attached to a Leica M205C stereomicroscope. Habitus photographs of the specimen were taken using a camera Nikon Coolpix 7100 .

Institutional abbreviations. MAPBAR, Museo Asociación Paleontológica Bariloche, San Carlos de Bariloche, Río Negro, Argentina.

Morphological abbreviations. AA, anterior anal; Ax1, Ax2, first and second primary antenodal brace; $\mathrm{CuA}$, anterior cubitus; $\mathrm{CuP}$, posterior cubitus; IR, intercalary radial veins; MA, anterior median; MP, posterior median; ' $\mathrm{O}$ ', oblique vein; RA, anterior radius; $\mathrm{RP}$, posterior radius; $\mathrm{ScP}$, posterior subcosta.

Systematic Palaeontology

Odonata Fabricius, 1793

Euzygoptera Bechly, 1996

Lestodea Bechly, 1996

Synlestidae sensu Bechly, 1996

Madres n. gen.

Type species: Madres delpueblo n. sp. (by monotypy); see below. 
Etymology. From Castilian madres, mothers. Dedicated to the Mothers and Grandmothers of Plaza de Mayo, especially to the Asociación Madres de Plaza de Mayo (AMPM) and to their President, Hebe de Bonafini. The Mothers of Plaza de Mayo met in 1977 looking for their sons that were Detained"Disappeared" by the last Civic-Military-Ecclesiastic Dictatorship from Argentina (1976-1983). The AMPM proclaimed in 1988 the socialization of their motherhood to the whole 30,000 disappeared (Morales 2017).

Diagnosis. As for the type species by monotypy.

\section{Madres delpueblo n. sp.}

Figures 1-3

Holotype: MAPBAR 4140, part and counterpart.

Type locality and Age: Río Pichileufú, Province of Río Negro, Patagonia, Argentina. Lutetian (ca. $48 \mathrm{Ma}$ ), middle Eocene.

Etymology. From Castilian del pueblo, from the people.

Diagnosis. The specimen is known by wing characters: Nodus and subnodus slightly oblique; smooth ScP kink at nodus; MP very curved after its origin; presence of vein "O"; base of RP3/4 one cell basal to nodus; IR2 aligned with subnodus; discoidal cell narrow and long; distal angle of discoidal cell very acute; Ax2 opposed to the arculus; $\mathrm{CuP}+\mathrm{AA}$ fused to the hind margin half of the length of the discoidal cell; base of RP2 9 cells distal of subnodus; CuP very distal and closer to $\mathrm{Ax} 2$ than to $\mathrm{Ax} 1$; four cells beneath pterostigma; longitudinal zigzagged vein between IR1 and RP2 two cells basal to pterostigma; longitudinal zigzagged vein between RP2 and IR2 from half of the pterostigma; and $\mathrm{CuA}$ short ending at the height of the IR2.

Description. Two superimposed hyaline hind (?) wings (Figures 1-2); length $46.6 \mathrm{~mm}, 4.1 \mathrm{~mm}$ wide; distance between base and arculus $4.7 \mathrm{~mm}$, arculus to nodus $3.2 \mathrm{~mm}$, nodus to pterostigma $17 \mathrm{~mm}$, pterostigma to apex $3.4 \mathrm{~mm}$; wing with long petiole, $4.3 \mathrm{~mm}$ long; two primary antenodals aligned with antesubnodals; supplementary antenodal crossveins absent; Ax1 $2.5 \mathrm{~mm}$ from the base of the petiole, and $2 \mathrm{~mm}$ to Ax2; Ax2 aligned with the arculus; distance between fork of MA and base of subnodus, $2.6 \mathrm{~mm}$; vein MAb oblique and long, distal angle of discoidal cell acute; discoidal cell elongate, narrow, $1.1 \mathrm{~mm}$ long, $0.2 \mathrm{~mm}$ wide, anterior side $0.35 \mathrm{~mm}$, posterior side sigmoidal $1.1 \mathrm{~mm}$, basal side $0.2 \mathrm{~mm}$, distal side $0.7 \mathrm{~mm}$; CuP short and straight, ending at the wing margin, closer to $\mathrm{Ax} 2$ than to $\mathrm{Ax} 1 ; \mathrm{CuP}+\mathrm{AA}$ fused to the hind margin half of the length of the discoidal cell; MP distally straight; MP very curved after its 


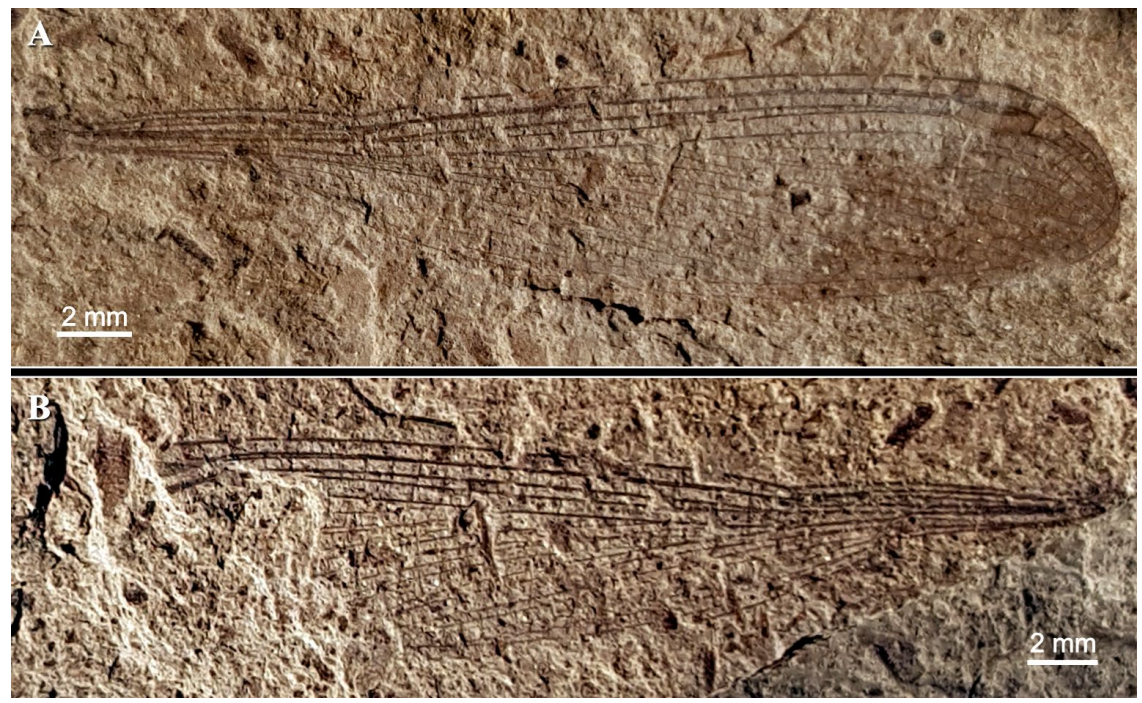

Figure 1. Photographs of the habitus of the malachite damselfly, Madres delpueblo $\mathrm{n}$. gen. n. sp., holotype MAPBAR 4140 from Río Pichileufú (Río Negro, Argentina); Lutetian, middle Eocene. Part (A), counterpart (B).

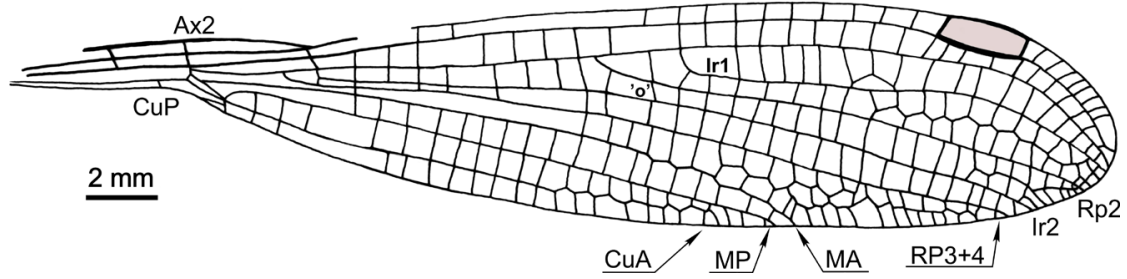

Figure 2. Camera lucida drawing of the malachite damselfly, Madres delpueblo n. gen. n. sp., holotype MAPBAR 4140 from Río Pichileufú (Río Negro, Argentina); Lutetian, middle Eocene.

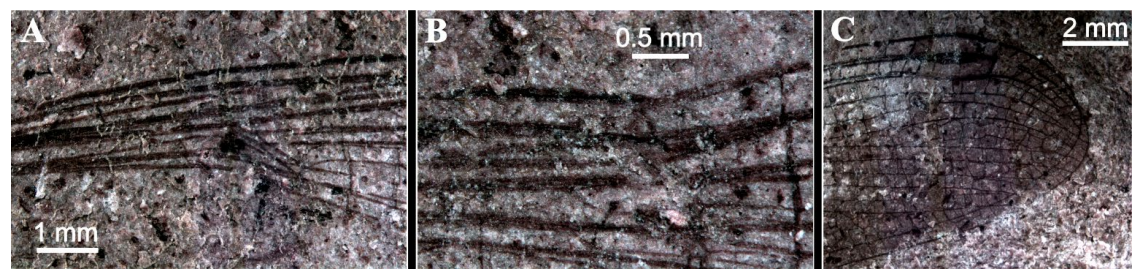

Figure 3. Details of hind (?) wings of the malachite damselfly, Madres delpueblo $\mathrm{n}$. gen. n. sp., holotype MAPBAR 4140 from Río Pichileufú (Río Negro, Argentina); Lutetian, middle Eocene. Basal part (A), middle part (B), distal part (C). 
origin at the distal angle of the discoidal cell; CuA zigzagged in its distal part, reaching posterior wing margin distal (three cells) of the level of base of RP2; one row of cells in cubito-anal area; one row of cells in area between MP and $\mathrm{CuA}, \mathrm{MA}$ and MP, RP3/4 and MA, IR2 and RP; MA basally straight, middle part curved and distally zigzagged at the height of IR1; anterior wing margin depressed at nodus; base of RP3/4 two cells basal to subnodus; base of IR2 opposite to subnodus; subnodus well oblique; base of RP2 8 cells distal of subnodus, 12 cells to pterostigma; a slightly oblique vein ' $\mathrm{O}$ ' two cells distal to the base of RP2; 19 postnodal crossveins; 6 distal postnodal and postsubnodal crossveins not aligned; IR1 arising 10 cells basal to pterostigma; two rows of cells between IR1 and RP2 two cells basal to pterostigma; pterostigma brown $2.4 \mathrm{~mm}$ long, $0.9 \mathrm{~mm}$ wide, somewhat braced, with its posterior side strongly curved; four cells beneath the pterostigma; 10 post-pterostigma cells between wing margin and RA.

Remarks. The wings are superimposed and seem to be hind wings, interpreted from Recent Synlestidae which have the discoidal cells of the hind wings more horizontal than that of the forewings. Wings are complete and not wrinkled as are in other specimens from the same locality (Petrulevičius 2017a) and especially in those of Laguna del Hunco (Petrulevičius 2013).

\section{Discussion}

The specimen has the synapomorphy of Lestoidea sensu Bechly, 1996, i.e., the arculus shifted basally beneath the Ax2. The new species could be included into Synlestidae sensu Bechly (1996) because it has the synapomorphy of the family, i.e., the posterior margin of the subdiscoidal cell mostly fused to the wing margin, and the MP strongly curved after their emergence from the discoidal cell. The Synlestidae sensu Bechly (1996) are composed of the Recent genera listed by Bridges (1994) for Synlestinae, i.e., Chlorolestes Selys, 1862, Euchlorolestes Kennedy, 1920, Ecchlorolestes Barnard, 1937, Episynlestes Kennedy, 1920, Phylolestes Christiansen, 1948, Sinolestes Needham, 1930, and Synlestes Selys, 1868. The family also includes Inacayalestes Petrulevičius, 2015 from the Ypresian of Patagonia.

The new species share with Phylolestes and Sinolestes the CuP extremely distal resulting closer to Ax2 than to Ax1 at least in the hindwings. Phylolestes was long regarded as enigmatic within Synlestidae as it is considered to have the posterior margin of the subdiscoidal cell not fused to the hind margin (Dijkstra et al. 2014). This character could be interpreted differently if we pay attention to the position of the $\mathrm{CuP}$ instead of the place of fusion of the subdiscoidal cell to the wing margin. The degree of fusion is quite similar in Phylolestes to that of Ecchlorolestes peringueyi and Inacayalestes aikunhuapi, being just basal to the arculus (subdiscoidal cell unfused in all the length of the discoidal cell). Therefore, the difference between these genera is the position of the CuP. While E. peringueyi and I. aikunhuapi have a more basal CuP, Phylolestes has a distal 
one, closer to the Ax2 than to the Ax1. Phylolestes and the new species share the distal place of the $\mathrm{CuP}$ but differ in the place of fusion of the subdiscoidal cell to the wing margin, more basal in Phylolestes. Sinolestes shares the same place of fusion of the subdiscoidal cell with the new species but differs in many characters, i.e., discoidal cells broader, IR2 some cells distal respect to the subnodus, and a denser venation. The other genera of Synlestidae could be excluded by the basal position of the CuP. The genera Chlorolestes, Ecchlorolestes, Inacayalestes and Synlestes have the CuP between the Ax1 and $\mathrm{Ax} 2$ but closer to the Ax1. The rest of the Synlestidae has the CuP basal to the Ax1. The new species also shares with Phylolestes a short CuA (also MA and MP) reaching the wing margin at the height of IR2. Synlestes weyersii Selys, 1869 resembles the new species but has a longer CuA (also MA and MP) reaching the wing margin distal to the arising of IR2.

\section{Concluding Remarks}

Herein, I report the second species of Synlestidae from the Eocene of Patagonia, and the third in the Americas (Recent Phylolestes, reported for the island of Hispaniola is the other genus). Patagonian species are the southernmost records of synlestids worldwide.

The new species is placed in a new genus Madres n. gen. by a unique combination of characters with respect to the genera of the family, i.e., the $\mathrm{CuP}$ closer to the $\mathrm{Ax} 2$, the discoidal cell very narrow, $\mathrm{CuP}+\mathrm{AA}$ fused to the hind margin half of the length of the discoidal cell, and a CuA short.

The present discovery of a new genus of Synlestidae in the Eocene of Patagonia is noteworthy for the reconstruction of the biogeographic and phylogenetic history of the Lestodea. The Eocene reveals a significant diversity, with three records in three localities from the Ypresian to the Lutetian of Patagonia and one from the Baltic region, suggesting a wider distribution for the entire family in the early Paleogene.

\section{Acknowledgements}

Thanks are due to the three reviewers of the manuscript, Enrique Peñalver (Instituto Geológico y Minero de España), and two anonymous, for helpful comments. Funding support for the fieldtrip and laboratory studies came from the following grants: PIP 0834 from the National Research Council of Argentina (CONICET), PICT-2016-4297 from the National Agency of Scientific and Technological Promotion of Argentina (ANPCyT).

\section{Literature Cited}

Bechly, G. 1996. Morphologische Untersuchungen am Flügelgeäder der rezenten Libellen und deren Stammgruppenvertreter (Insecta; Pterygota; Odonata), unter besonderer Berücksichtigung der Phylogenetischen Systematik und des Grundplanes der *Odonata. Petalura 2:1-402.

Bechly, G. 2007. Phylogenetic Systematics of Odonata. https://bechly.lima-city.de/system.htm (Last accessed on July 15,2018 ).

Bechly, G. and W. Wichard. 2008. Damselfly and dragonfly nymphs in Eocene Baltic amber (Insecta: Odonata), with aspects of their palaeobiology. Palaeodiversity 1:37-74.

Dlussky, G. M. and K. S. Perfilieva. 2003. Paleogene ants of the genus Archimyrmex Cockerell, 1923 (Hymenoptera: Formicidae: Myrmeciinae). Paleontological Journal 37(1):39-47. 
Fidalgo, P. and D. R. Smith. 1987. A fossil Siricidae (Hymenoptera) from Argentina. Entomological News 98:63-66.

Greenwalt, D. E. and G. Bechly. 2014. A re-description of the fossil damselfly Eolestes syntheticus Cockerell, 1940 (Odonata: Zygoptera: Eolestidae n. fam.) with description of new taxa from the Eocene of North America. Zootaxa 3887(2):138-156. https://doi.org/10.11646/zootaxa.3887.2.2

Kukalová-Peck J. 1983. Origin of the insect wing and wing articulation from the arthropodan leg. Canadian Journal of Zoology 61:1618-1669. https://doi.org/10.1139/z83-217

Kukalová-Peck, J., 1991. Fossil history and the evolution of hexapod structures, pp. 141-179. In, Naumann, I. D. (Editor). The Insects of Australia, a Textbook for Students and Research Workers (2nd Edition). Vol. 1. Melbourne University Press. Melbourne, Australia. 542 pp.

Kukalová-Peck, J., 2008. Phylogeny of higher taxa in Insecta: Finding synapomorphies in the extant fauna and separating them from homoplasies. Evolutionary Biology 35:4-51. https://doi.org/10.1007/s11692-007-9013-4

Lak, M., G. Fleck, D. Azar, M. S. Engel, H. F. Kaddumi, D. Neraudeau, P. Tafforeau, and A. Nel. 2009. Phase contrast X-ray synchrotron imaging and the oldest damselflies in amber (Odonata: Zygoptera: Hemiphlebiidae). Zoological Journal of the Linnean Society 156 (4):913-923. https://doi.org/10.1111/j.1096-3642.2008.00497.x

Morales, M. V. 2017. Escisión y dos modos de ser "Madres de Plaza de Mayo": tensión y complejidad en la socialización de la maternidad. Estudios de Género de El Colegio de México 3(6):36-68. https://dx.doi.org/10.24201/eg.v3i6.140

Nel, A. and A. Arillo. 2006. The first Baltic amber dysagrionine damselfly (Odonata: Zygoptera: Thaumatoneuridae: Dysagrioninae). Annales de la Société Entomologique de France 42(2): 179-182. https://doi.org/10.1080/00379271.2006.10700621

Nel, A., D.-Y. Huang, and Q.-B. Lin. 2008. A new genus of isophlebioid damsel-dragonflies with "calopterygid"-like wing shape from the Middle Jurassic of China (Odonata: Isophlebioidea: Campterophlebiidae). European Journal of Entomology 105(4):783-787. https://doi.org/10.14411/eje.2008.103

Nel, A., X. Martínez-Delclòs, J. C. Paicheler, and M. Henrotay. 1993. Les 'Anisozygoptera' fossiles. Phylogénie et classification. (Odonata). Martinia, Numéroors-série 3: 1-311.

Petrulevičius, J. F. 2001. Cenozoic insects from Argentina. Biogeographical aspects. Proceedings of the First International Meeting on Paleoarthropodology, Special Issue of Acta Geologica Leopoldensia 24(52-53):137-144.

Petrulevičius, J. F. 2005. Avances en el conocimiento de la diversidad de insectos de Laguna del Hunco, Eoceno inferior de Chubut, Patagonia, Argentina. Ameghiniana 42 (4) Supl.: 40R. Petrulevičius, J. F. 2009. A Panorpoidea (Insecta: Mecoptera) from the lower Eocene of Patagonia, Argentina. Journal of Paleontology 83: 994-997. https://doi.org/10.1666/08-073.1

Petrulevičius, J. F. 2013. Palaeoenvironmental and palaeoecological implications from body fossils and ovipositions of Odonata from the Eocene of Patagonia, Argentina. Terrestrial Arthropod Reviews 6:53-60. https://doi.org/10.1163/18749836-06021057

Petrulevičius, J. F. 2015. A new Synlestidae damselfly (Insecta: Odonata: Zygoptera) from the early Eocene of Nahuel Huapi Este, Patagonia, Argentina. Arquivos Entomolóxicos 14:287-294.

Petrulevičius, J. F. 2016. A new pentatomoid bug from the Ypresian of Patagonia, Argentina. Acta Palaeontologica Polonica 61(4):863-868. https://doi.org/10.4202/app.00308.2016

Petrulevičius, J. F. 2017a. First Frenguelliidae (Insecta: Odonata) from the middle Eocene of Río Pichileufú, Patagonia, Argentina. Arquivos Entomolóxicos 18:367-374.

Petrulevičius, J. F. 2017b. A new burmagomphid dragonfly from the Eocene of Patagonia, $\begin{array}{lllll}\text { Argentina. Acta } & \text { Paleontologica Polonica } & 62 & \text { (4): }\end{array}$ https://doi.org/10.4202/app.00427.2017.

Petrulevičius, J. F. and A. Nel. 2003. Frenguelliidae, a new family of dragonflies from the earliest Eocene of Argentina (Insecta: Odonata). Phylogenetic relationships within Odonata. Journal of Natural History 37: 2909-2918. https://doi.org/10.1080/0022293021000007543

Petrulevičius, J. F. and A. Nel. 2005. Austroperilestidae, a new family of damselflies from the earliest Eocene of Argentina (Insecta: Odonata). Phylogenetic relationships within Odonata. 
Journal of Paleontology 79: 658-662. https://doi.org/10.1666/00223360(2005)079[0658:AANFOD]2.0.CO;2

Petrulevičius, J. F. and A. Nel. 2007. Enigmatic and little known Odonata (Insecta) from the Paleogene of Patagonia and northwest Argentina. Annales de la Societé Entomologique de France 43:341-347. https://doi.org/10.1080/00379271.2007.10697530

Petrulevičius, J. F. and A. Nel. 2013. A new Frenguelliidae (Insecta: Odonata) from the early Eocene of Laguna del Hunco, Patagonia, Argentina. Zootaxa 3616: 597-600. https://doi.org/10.11646/zootaxa.3616.6.6

Petrulevičius, J. F. and P. R. Gutiérrez. 2016. New basal Odonatoptera (Insecta) from the Lower Carboniferous (Serpukhovian) of Argentina. Arquivos Entomolóxicos 16: 341-358.

Petrulevičius, J. F., A. Nel, and J. F. Voisin. 2010. Discovery of a new genus and species of darner dragonfly (Aeshnidae: Odonata) from the lower Eocene of Laguna del Hunco, Patagonia, Argentina. In, Nel, A., D. Azar, and J. F. Petrulevičius (Editors). Fossil insects, Systematics, Phylogeny and Palaeoecology. Special issue Annales de la Société Entomologique de France 46:271-275.

Petrulevičius, J. F. and Y. Popov. 2014. First fossil of Discocephalinae (Insecta: Heteroptera): a new genus from the Eocene of Patagonia, Argentina. Zookeys 422:23-33. https://doi.org/10.3897/zookeys.422.6750

Riek, E. F. and J. Kukalová-Peck. 1984. A new interpretation of dragonfly wing venation based upon Early Carboniferous fossils from Argentina (Insecta: Odonatoidea) and basic characters states in pterygote wings. Canadian Journal of Zoology 62:1150-1166. https://doi.org/10.1139/z84-166

Rossi de García, E., 1983. Insectos de la Formación Ventana (Eoceno). Provincia de Neuquén. Revista de la Asociación Geológica Argentina 38:17-23.

Sarzetti, L. C., C. C. Labandeira, J. Muzón, P. Wilf, N. R. Cúneo, K. R. Johnson, and J. F. Genise. 2009. Odonatan endophytic oviposition from the Eocene of Patagonia: the ichnogenus Paleoovoidus and implications for behavioural stasis. Journal of Paleontology 83:431-447. https://doi.org/10.1666/08-121.1

Schorr, M. and D. Paulson. 2018. World list of Odonata. http://www.pugetsound.edu/academics/academic-resources/slater-museum/biodiversityresources/dragonflies/world-odonata-list2/ (Last accessed on July 15, 2018). Tsuda, S. 2000. A Distributional List of World Odonata. 2000. Privately published. Osaka, Japan. 430 pp.

Viana, M. J. and J. A. Haedo-Rossi. 1957. Primer hallazgo en el hemisferio sur de Formicidae extinguidos y catálogo mundial de los Formicidae fósiles. Ameghiniana 1:108-113.

Wilf, P. 2012. Rainforest conifers of Eocene Patagonia: attached cones and foliage of the extant southeast-Asian and Australasian genus Dacrycarpus (Podocarpaceae). American Journal of Botany 99:562-584. https://doi.org/10.3732/ajb.1100367

Wilf, P., N. R. Cúneo, K. R. Johnson, J. F. Hicks, S. L.Wing, and J. D. Obradovich. 2003. High plant diversity in Eocene South America: Evidence from Patagonia. Science 300:122-125. https://doi.org/10.1126/science.1080475

Wilf, P., K. R. Johnson, N. R., Cúneo, M. E. Smith, B. S. Singer, and M. A. Gandolfo. 2005. Eocene plant diversity at Laguna del Hunco and Río Pichileufú, Patagonia, Argentina. The American Naturalist 165:634-650. https://doi.org/10.1086/430055

Zheng, D., A. Nel, S.-C. Chang, E. A. Jarzembowski, H. Zhang, and B. Wang. 2017. A wellpreserved true dragonfly (Anisoptera: Gomphides: Burmagomphidae fam. nov.) from Cretaceous Burmese amber. Journal of Systematic Palaeontology 16(10): 881-889. https://doi.org/10.1080/14772019.2017.1365100 